\title{
Memory retrieval improvement by Heteropterys aphrodisiaca in aging rats
}

\author{
Suzana Maria Pereira Galvão ${ }^{1 *}$, Fúlvio Rieli Mendes $^{2}$, Maria Gabriela Menezes de Oliveira ${ }^{3}$, \\ Rita Mattei ${ }^{3}$, João Carlos Palazzo de Mello $^{4}$, Walter Antonio Roman Júnior ${ }^{5}$, \\ Elisaldo de Araújo Carlini ${ }^{3}$
}

\author{
${ }^{1}$ Center for Health Sciences, Universidade Estadual do Piaui, ${ }^{2}$ Center of Natural Sciences and Humanities, Universidade \\ Federal do ABC, ${ }^{3}$ Department of Psychobiology, Universidade Federal de São Paulo, ${ }^{4}$ Department of Pharmacy, Universidade \\ Estadual de Maringá, ${ }^{5}$ Laboratory of Pharmacognosy, Universidade Comunitária Regional de Chapecó
}

Few data exists about the pharmacological properties of Heteropterys aphrodisiaca O. Mach. (Malpighiaceae), which is native to the scrubland regions of Brazil. The present study investigated the effects of oral treatment with H. aphrodisiaca extract (BST0298) on the learning and memory of young (3-6 months) and aged (21-23 months) rats, and compared the in vitro antioxidant activity of three lots collected in different years. An improvement in the number of sessions to learn the task was observed in the left/right discrimination test in aged rats treated for 45 days with $25 \mathrm{mg} / \mathrm{kg}(7.0 \pm 0.5 ; p=0.005)$ or 50 $\mathrm{mg} / \mathrm{kg}(7.6 \pm 0.6 ; p=0.012)$ compared with control old rats $(11.0 \pm 1.6)$. On the other hand, pre-treatment did not improve the performance of scopolamine-treated mice in the passive avoidance test. The in vitro malondialdehyde test showed that all three different extracts presented similar antioxidant activity. The flavonoids astilbin, isoastilbin and neoastilbin were isolated from the extract and may contribute to the biological activity. These results suggest that repeated treatment with $H$. aphrodisiaca improves learning and memory, probably by a non-muscarinic mechanism.

Uniterms: Heteropterys aphrodisiaca O. Mach/pharmacognosy. Heteropterys aphrodisiaca O. Mach/ antioxidant activity. Malpighiaceae/pharmacognosy. Antioxidants. Flavonoids. Plant extract.

Existem poucos dados disponíveis sobre as propriedades farmacológicas da Heteropterys aphrodisiaca O. Mach. (Malpighiaceae), nativa da região do pantanal brasileiro. O presente estudo investigou o efeito do tratamento oral com um extrato de $H$. aphrodisiaca (BST0298) sobre a memória e aprendizagem de ratos jovens (3-6 meses) e idosos (21-23 meses) e comparou a atividade antioxidante in vitro de três lotes, coletados em diferentes anos. Melhora quanto ao número de sessões necessárias para aprender a tarefa foi observada no teste de discriminação direita/esquerda em ratos idosos tratados por 45 dias com doses de $25 \mathrm{mg} / \mathrm{kg}(7,0 \pm 0,5 ; p=0,005)$ e $50 \mathrm{mg} / \mathrm{kg}(7,6 \pm 0,6 ; p=0,012)$ comparados com ratos idosos controle $(11,0 \pm 1,6)$. Por outro lado, o pré-tratamento com o extrato não melhorou o desempenho de camundongos tratados com escopolamina no teste da esquiva passiva. Em relação à avaliação da atividade antioxidante in vitro pelo teste do malonodialdeído, os três lotes analisados apresentaram atividade antioxidante semelhante. Os flavonóides astilbina, isoastilbina e neoastilbina foram isolados do extrato e podem contribuir para a atividade biológica. Estes resultados sugerem que a administração repetida de H. aphrodisiaca melhora a memória e aprendizagem provavelmente por um mecanismo não muscarínico.

Unitermos: Heteropterys aphrodisiaca O. Mach/farmacognosia. Heteropterys aphrodisiaca O. Mach/ atividade antioxidante. Malpighiaceae/farmacognosia. Antioxidantes. Flavonóides. Extrato vegetal.

*Correspondence: S.M.P. Galvão. Centro de Ciências da Saúde, Universidade Estadual do Piauí. Rua Olavo Bilac, 2335, 64001-280 - Teresina - PI, Brazil. E-mail: smpgalvao@gmail.com 


\section{INTRODUCTION}

Heteropterys aphrodisiaca O. Mach. (Malpighiaceae) is a Brazilian plant whose roots in "cachaça" (an alcoholic drink) are used as an aphrodisiac, tonic or stimulant, as well as for nervous debility (Corrêa, 1984; Pott, Pott, 1994). It is mainly found in the scrubland regions of the Brazilian states of Mato Grosso and Goiás (Corrêa, 1984), and is known as "nó-de-cachorro" (Pott, Pott, 1994). H. aphrodisiaca and other plants considered tonics by the general population are taken chronically - as are adaptogenic plants - with the aim of improving general health and for their preventive effect in relation to a wide range of health problems (Mendes, Carlini, 2007).

Various studies have shown that adaptogenic plants affect the nervous system, improving cognitive functions by slowing down the deterioration of cognitive processes observed in elderly people. For instance, Panax ginseng C.A. Mey. (Araliaceae), a classical adaptogenic plant, has been shown to restore the learning and memory deficits of aged rats evaluated in a two-way active avoidance test (Petkov, Belzheva, Petkov, 2003) and in an 8-arm radial maze (Nitta et al., 1995). It has also been shown to restore impaired acquisition of scopolamine and ethanol-treated rats in passive avoidance performance studies (Hsieh et al., 2000; Lee, Moon, You, 2000).

Our previous studies have shown that a hydroalcoholic extract of $H$. aphrodisiaca (BST0298 extract) had a positive effect on memory in aged rats when evaluated in a passive avoidance test, after 7 or 26 days of treatment (dose of $100 \mathrm{mg} / \mathrm{kg}$ ), and in a left/right discrimination test in a T-maze, after 109 days of treatment with $50 \mathrm{mg} / \mathrm{kg}$ (Galvão, 1997; Galvão et al., 2002). The extract BST0298 also showed both in vitro and in vivo antioxidant effects (Mattei et al., 2001). On the other hand, acute treatment with the extract $(100 \mathrm{mg} / \mathrm{kg})$ had no effect on the passive avoidance test (Galvão et al., 2002).

It is important to determine the smallest active dose of a compound and the minimal time necessary to obtain the desired action, which can be useful to diminish the possibility of toxic effects. These data led us to investigate the effects of the extract BST0298, prepared from the roots of $H$. aphrodisiaca, on the memory and learning capacity of aged rats, to verify whether a smaller dose and a shorter period of treatment would also be efficient in these performance tests.

\section{MATERIAL AND METHODS}

\section{Animals}

We used 150 male Swiss albino mice, 3 months old, and 69 male Wistar rats, 3-6 months old (young) and 21-23 months old (aged) at the beginning of the study, provided by the Department of Psychobiology, Universidade Federal de São Paulo. The animals were housed in standard polypropylene cages $(30 \times 38 \mathrm{~cm}$ sides; $17 \mathrm{~cm}$ high $)$ in groups of five (rats) and twenty (mice), and kept in a room with a controlled temperature $\left(23 \pm 2{ }^{\circ} \mathrm{C}\right)$ and light-dark cycle (lights on from 7 a.m. to 7 p.m.). Food and water were freely available.

The procedures adopted were approved by the UNIFESP ethical committee (protocol number 295/00) and according to the norms recommended by the International Guiding Principles for Biomedical Research involving Animals (CIOMS) - Geneva, 1985.

\section{Plant material}

Heteropterys aphrodisiaca $\mathrm{O}$. Mach. roots were collected over a three-year period during the Brazilian autumn (March, 1996 - lot 1; April, 1998 - lot 2; April, 1999 - lot 3) in Santo Antônio do Leverger, Mato Grosso State, Brazil ( $30^{\circ} 28^{\prime} 31^{\prime \prime}$ S and $\left.51^{\circ} 35^{\prime} 25^{\prime \prime} \mathrm{W}\right)$. The plants were identified by Dr. Miramy Macedo, and a voucher specimen was deposited in the herbarium at the Federal University of Mato Grosso (UFMT), Brazil, under number 22,181 . Lot 1 was investigated in our previous studies (Mattei et al., 2001; Galvão et al., 2002).

\section{Drugs}

Scopolamine hydrobromide and thiobarbituric acid were purchased from Sigma Chemical Company (St. Louis, MO, USA). Scopolamine was diluted in water. The plant extract was prepared by dissolving the lyophilized material in distilled water in such a volume as to administer orally (gavage) the desired dose in $0.1 \mathrm{~mL}$ per $100 \mathrm{~g}$ body weight for rats and $0.1 \mathrm{~mL}$ per $10 \mathrm{~g}$ for mice. Doses of 25 and $50 \mathrm{mg} / \mathrm{kg}$ were used for 45-day treatment (rats evaluated on the T maze), and 100, 200, and $400 \mathrm{mg} / \mathrm{kg}$ for shorter treatments (from 1 to 21 days; mice evaluated on the passive avoidance test).

\section{Preparation of extract BST0298 and isolation of polyphenolic compounds}

The roots of $H$. aphrodisiaca were crushed and powdered using a grinding mill. The standardized extract, designated BST0298, was prepared by turbo extraction as described by Voigt (1993), using a 50\% water-ethanol solvent.

The lyophilized BST0298 extract (300 g) was redis- 
solved in 3,000 $\mathrm{mL} \mathrm{H}_{2} \mathrm{O}$ and extracted with EtOAc $(30 \mathrm{~L})$. After evaporation of solvents, the EtOAc fraction and the remaining $\mathrm{H}_{2} \mathrm{O}$ phase gave dark-brown solids of $16.2 \mathrm{~g}$ and $265.6 \mathrm{~g}$, respectively. A portion ( $15 \mathrm{~g})$ of EtOAc fraction was subjected to column chromatography on Sephadex LH-20 [710×50 mm; eluents: 50\% EtOH, $100 \% \mathrm{EtOH}$, and $70 \% \mathrm{Me}_{2} \mathrm{CO} ; 10 \mathrm{~mL}$ fractions] afforded 10 subfractions (Roman Júnior, 2003).

Subfraction VI $(251.5 \mathrm{mg})$ yielded a pure compound identified as isoastilbin [3-O- $\alpha$-L-rhamnosyl-cis- $(2 R, 3 S)$ taxifolin] (40 mg) (1). Subfraction VII (2,300.6 mg) was purified through crystallization to yield the pure compound astilbin [3-O- $\alpha$-L-rhamnosyl-trans- $(2 R, 3 R)$-taxifolin] (120 mg) (2). Subfraction VIII (1,095.4 mg) was subjected to CC on Sephadex LH-20 [320×35 mm; eluent: $50 \% \mathrm{EtOH}(2 \mathrm{~L}) ; 10 \mathrm{~mL}$ fractions] giving 3 subfractions (VIII-1, VIII-2, and VIII-3). Subfraction VIII-3 (240 mg) resulted in the pure compound neoastilbin [3-O- $\alpha-\mathrm{L}-$ rhamnosyl-trans-(2S,3S)-taxifolin] (3) (Figure 1).

All NMR spectra of the compounds $(\mathbf{1 - 3})\left({ }^{1} \mathrm{H},{ }^{13} \mathrm{C}\right.$, COSY, DEPT, HETCOR) were recorded in $\mathrm{CD}_{3} \mathrm{OD}$ on a Varian Mercury 300BB (300 MHz) at ambient temperature with TMS as the internal standard. CD data were obtained in $\mathrm{MeOH}$ on a Jasco J-815. ESI-MS mass spectrometer: Quattro LCZ, Firma Waters, was measured in the positiveion mode. Polarimetry was measured in a Perkin Elmer mod. 343. L-rhamnose was identified (TLC) after acid hydrolysis using the method described by Kartinig and Wegschaider (1971).

\section{Left/right discrimination test}

Rats were individually trained and tested in a Tmaze with arms $60 \mathrm{~cm}$ long by $10 \mathrm{~cm}$ wide and walls $3 \mathrm{~cm}$ high. The maze was raised $1 \mathrm{~m}$ above the floor. One piece of cereal, $150 \mathrm{mg}$ of Froot Loops (Kellogg Brazil Ltda., São Paulo, Brazil), was placed at the end of each arm as reinforcement. The apparatus was placed in the center of a room which contained spatial cues and was cleaned with
$20 \%$ alcohol after each run to prevent olfactory cues during training. The procedure is described bellow.

\section{Treatment of naïve rats for 45 days}

Three groups of aged rats $(n=18)$ were orally treated for 45 days with 25 and $50 \mathrm{mg} / \mathrm{kg}$ of BST0298 extract (lot $3)$ or water $(n=15)$. A young group of rats $(n=10)$ received water.

On the $11^{\text {th }}$ day of treatment, the animals started the learning phase in the T maze. The treatment was given in the morning and the training between 1:00 p.m. and 6:00 p.m. The animals were placed individually in the maze for $5 \mathrm{~min}$ without the presence of reinforcement. This procedure was repeated on the $13^{\text {th }}$ and $15^{\text {th }}$ days.

On the $16^{\text {th }}$ day, the reward was placed at the both ends of the maze arms and the animals, which had been starved for the preceding 20 hours, were placed individually in each arm for one minute. This procedure was performed on alternate days and was repeated 6 more times.

On the $29^{\text {th }}$ day, the training phase of the T maze left/ right discrimination test began with $50 \%$ of the rats from each group randomly selected and reinforcement placed in the right arm. For the other $50 \%$, reinforcement was placed in the left arm. The reinforced arm (correct arm) remained constant throughout the training period. On alternate days the animals were subjected to training sessions, each of which was composed of six consecutive runs. Each run started with the animal being placed at the start-arm, and if it chose the correct side-arm, it received the reward. If the animal chose the incorrect side-arm, it was confined in the arm for $30 \mathrm{~s}$ without a reward. The animal was then placed at the start-arm for the next run. The time limit for the animal to enter one of the side-arms was $5 \mathrm{~min}$. If it did not enter a side-arm in $5 \mathrm{~min}$, it was confined in the incorrect side-arm for $30 \mathrm{~s}$ without a reward. The rats were trained until they achieved the learning criteria of at least two consecutive sessions without an error (12 correct runs) or until they had had 20 training sessions (the training ceiling) (Galvão et al., 2007).

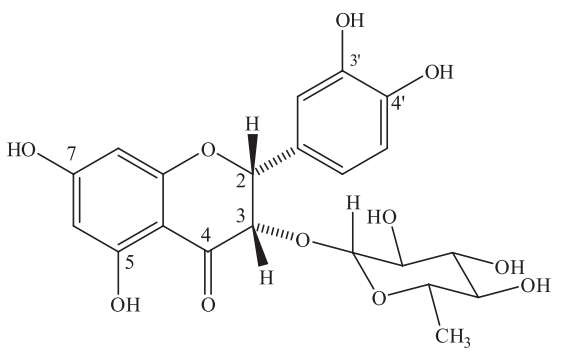

Isoastilbin (1)

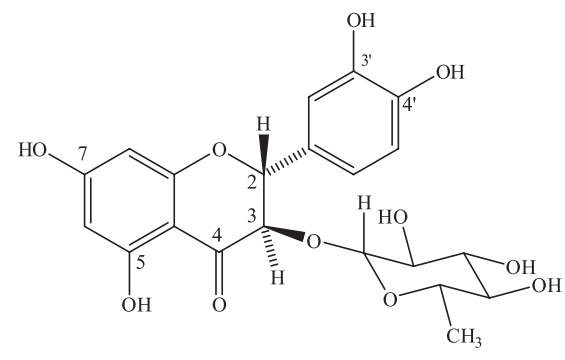

Astilbin (2)

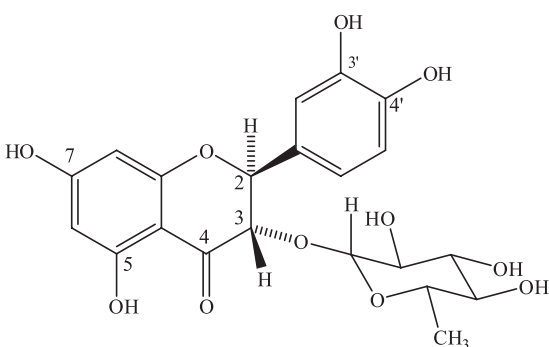

Neoastilbin (3)

FIGURE 1 - Isolated flavonoids of the extract of Heteropteris aphrodisiaca. (1) isoastilbin, (2) astilbin and (3) neoastilbin. 


\section{Reversion of the amnesic effect of scopolamine in young mice}

\section{Acute treatment}

Groups of 10 mice were acutely administered BST0298 extract (lot 2) orally in doses of 100, 200 or $400 \mathrm{mg} / \mathrm{kg}$ or water (control group). Thirty minutes later, the mice received a scopolamine injection $(0.5 \mathrm{mg} / \mathrm{kg}$, i.p). A fifth group received water (orally) and, after $30 \mathrm{~min}$, saline (i.p.) instead of scopolamine.

Thirty minutes after scopolamine or water administration, the animals were evaluated in the passive avoidance apparatus (acquisition training). Each mouse was placed in the light compartment with the connecting door closed and after $10 \mathrm{~s}$ the door was opened and the time taken for the animal to cross into the dark compartment was recorded. As soon as the animal entered the dark compartment the door was closed and one shock of $1.0 \mathrm{~mA}$ lasting $2 \mathrm{~s}$ was applied to the animal's paw. Immediately afterwards, the animal was removed from the apparatus. The maximum time allowed for an animal to cross into the dark compartment was 180 s (Galvão et al., 2002).

\section{7- and 21-day treatment}

Four groups of 10 mice each were orally treated for 7 days with water (controls) or the BST0298 extract (lot 2) in doses of $100,200 \mathrm{or} 400 \mathrm{mg} / \mathrm{kg}$. On the $8^{\text {th }}$ treatment day, mice were administered scopolamine $(0.5 \mathrm{mg} / \mathrm{kg}$, i.p.) (or water for the controls) and were subjected to the passive avoidance test as described earlier. A fifth group received scopolamine but no extract.

The same procedure was carried out in mice treated for 21 days with the extract.

\section{Antioxidant activity in vitro}

In this study, lots 2 and 3 of the BST0298 extract were evaluated. Male rats were anesthetized with diethyl ether and the brains were perfused with $0.1 \mathrm{~mol} / \mathrm{L}$ phosphate buffer $\mathrm{pH}$ 7.4. The rats were then decapitated and the brains quickly excised for homogenization in the same buffer (1:4 $\mathrm{w} / \mathrm{v})$. The homogenates were centrifuged at $3000 \mathrm{rpm}$ for 15 $\min \left(4^{\circ} \mathrm{C}\right)$ and the pellets discarded. The cleared samples were used for evaluation of lipid peroxidation for $1 \mathrm{~h}$ at $37^{\circ} \mathrm{C}$ in the presence of different extract concentrations. Products of spontaneous lipid peroxidation react with thiobarbituric acid to form a colored compound, the intensity of which is measured at $535 \mathrm{~nm}$ in a spectrophotometer (Stocks et al., 1974; Mattei et al., 2001). The concentration of the extract that inhibits $50 \%$ of peroxidation is referred to as $\mathrm{Q}_{1 / 2}$, and it was calculated after 3-5 assays.

\section{Statistical analysis}

The latency of entry into the dark box in the passive avoidance test with mice was analyzed using the Kruskal-Wallis test followed by the Mann-Whitney U test. The number of sessions required to achieve the learning criteria in the left/right discrimination task was analyzed using one-way analysis of variance (ANOVA) followed by Duncan's post-hoc test. $p \leq 0.05$ was considered to be statistically significant. The antioxidant activity was calculated using a linear regression method $\left(\right.$ GraphPad Prism $\left.{ }^{\circledR}\right)$.

\section{RESULTS}

\section{Left/right discrimination test}

As can be seen in Figure 2, there were statistically significant differences between the groups [one way ANOVA: $\mathrm{F}(3,50)=4.294338 ; p=0.008]$. Duncan's post hoc test ( $p=0.005$ ) showed that the rats of the aged control group needed a greater number of sessions (11.0 \pm 1.6$)$ to achieve the learning criteria when compared with the young control group (7.1 \pm 0.6$)$. The aged rats treated for 45 days with 25 or $50 \mathrm{mg} / \mathrm{kg}$ of BST0298 extract showed similar performance to the young control rats $(7.0 \pm 0.5$, $7.6 \pm 0.6$, respectively) (Duncan: $p=0.93$ for $25 \mathrm{mg} / \mathrm{kg}$; $p=0.68$ for $50 \mathrm{mg} / \mathrm{kg}$ ), and clearly displayed a better performance than the aged control rats (Duncan: $p=0.005$ for $25 \mathrm{mg} / \mathrm{kg}$; $p=0.012$ for $50 \mathrm{mg} / \mathrm{kg}$ ).

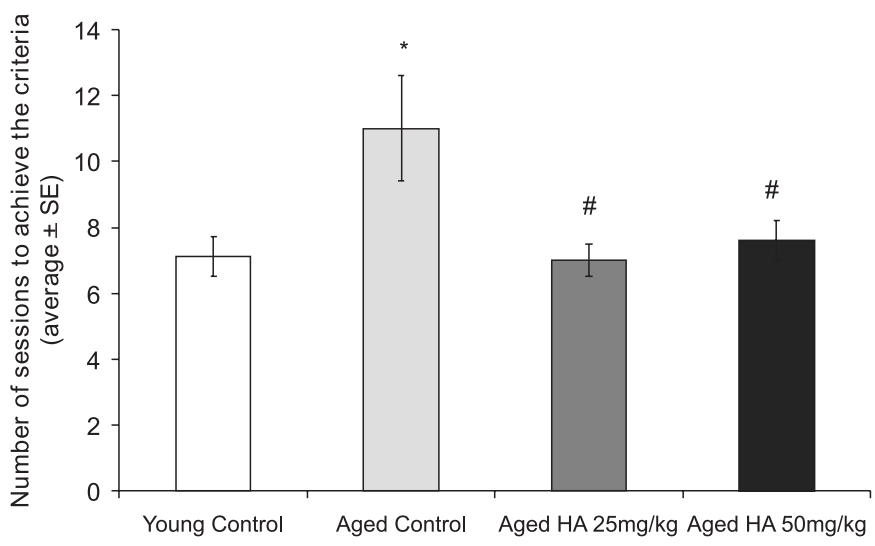

FIGURE 2 - Number of sessions required to achieve the learning criteria in the T maze by young control rats $(\square)$, aged control rats ( $\square$ ) and aged rats treated with $25 \mathrm{mg} / \mathrm{kg}(\square)$ or $50 \mathrm{mg} / \mathrm{kg}(\square)$ of Heteropterys aphrodisiaca extract (HA) for 45 days. The values are expressed as mean \pm standard error. *Statistically different from the young control group $(p<0.05)$. \#Statistically different from the aged control group $(p<0.05)$. 1-ANOVA followed by Duncan. 


\section{Reversion of the amnesic effect of scopolamine in young mice}

\section{Acute treatment}

As shown in Figure 3, there were no statistically significant differences among the groups in the acquisition phase, as expected [Kruskal-Wallis: $\mathrm{H}=6.5788 ; p=0.16$ ]. However, in the retention phase, statistically significant differences were found between the groups [Kruskal-Wallis: $\mathrm{H}=19.8173 ; p=0.0005]$. The scopolamine control group entered the dark compartment with a lower latency, in comparison to the control (no scopolamine) mice, demonstrating impairment in the passive avoidance test (Mann-Whitney: $\mathrm{U}=0.0 ; p=0.000094)$. Mice previously treated with the BST0298 extract (acutely) plus $0.5 \mathrm{mg} / \mathrm{kg}$ scopolamine did not present a reversal of scopolamine-induced memory impairment in the passive avoidance test, presenting similar behavior as animals receiving only scopolamine (MannWhitney: $\mathrm{U}=36.5 ; p=0.30$ for $100 \mathrm{mg} / \mathrm{kg}$; $\mathrm{U}=32.0 ; p=0.17$ for: $200 \mathrm{mg} / \mathrm{kg}$; $\mathrm{U}=34.0 ; p=0.22$ for $400 \mathrm{mg} / \mathrm{kg}$ ) (Figure 3).

\section{7- and 21-day treatment}

There were statistically significant differences between the groups in the retention phase on 7-day treatment [Kruskal-Wallis: $\mathrm{H}=15.1881 ; p=0.0043$ ] and 21-day treatment tests [Kruskal-Wallis: $\mathrm{H}=20.6927 ; p=0.0004]$. The scopolamine control group was statistically different from the control (no scopolamine) group in the retention phase, both on 7-day (Mann-Whitney: $\mathrm{U}=0.0 ; p=0.000071$ ) and 21-day treatment (Mann-Whitney: $\mathrm{U}=0.0 ; p=0.00003$ ), demonstrating impairment in the passive avoidance test. However, neither 7 nor 21-day treatment with the BST0298 extract reverted scopolamine-induced memory impairment in mice (data not shown).

\section{Antioxidant activity}

The antioxidant effect of the extract (lot 2 and lot 3 ) is indicated in Table I. An inhibition of 50\% of spontaneous lipid peroxidation $\left(\mathrm{Q}_{1 / 2}\right)$ can be observed for lot 2 $(3.9 \pm 0.3 \mu \mathrm{g} / \mathrm{mL})$ and lot $3(3.6 \pm 0.1 \mu \mathrm{g} / \mathrm{mL})$, indicating that the plant collected during the same season but

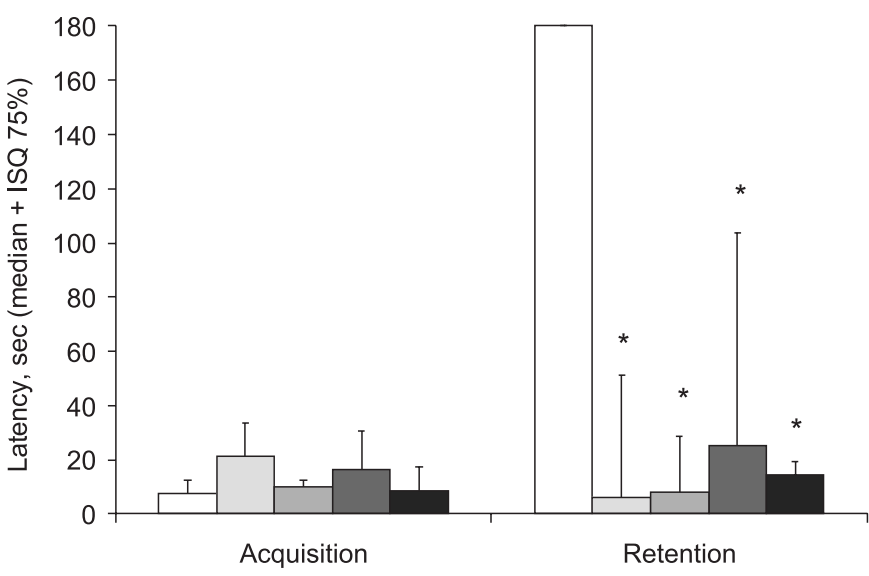

FIGURE 3 - Latency for the acquisition and retention (24h later) phases of the passive avoidance test by control (no scopolamine) mice ( $\square$ ), control mice treated acutely with water $+0.5 \mathrm{mg} / \mathrm{kg}$ of scopolamine $(\square)$, and experimental mice treated with $100 \mathrm{mg} / \mathrm{kg}(\square), 200 \mathrm{mg} / \mathrm{kg}(\square)$ or $400 \mathrm{mg} / \mathrm{kg}(\square)$ of the extract of Heteropterys aphrodisiaca + scopolamine $0.5 \mathrm{mg} / \mathrm{kg}$. The values are expressed as medians + semi-interquartile ranges. * Statistically different from the control (no scopolamine) group $(p<0.05)$. Kruskal-Wallis followed by Mann-Whitney.

in different years maintained antioxidant activity within the same range, similar to that of lot 1 collected in 1996 $\left(\mathrm{Q}_{1 / 2}=3.3 \mu \mathrm{g} / \mathrm{mL}\right)$ (Mattei et al., 2001).

\section{DISCUSSION}

Many authors have studied the deterioration in learning and memory which occurs with aging and have correlated it to anatomical and biochemical alterations in the central nervous system. In this context, it is possible to study drugs that may reduce this deterioration or restore learning and impaired memory in old age.

Our results obtained with the T maze confirmed the positive effects of BST0298 extract. Previous studies have shown that old rats treated with $50 \mathrm{mg} / \mathrm{kg}$ of extract (lot 1) for 109 days achieved the learning criteria in a number of sessions practically equal to the number achieved by the young animals and faster than the old control animals (Galvão et al., 2002). In the present study, aged rats were

TABLE I - Antioxidant activity in vitro (inhibition of $50 \%$ of spontaneous lipoperoxidation: $\mathrm{Q}_{1 / 2}$ ) of two lots of BST0298 extract from Heteropterys aphrodisiaca

\begin{tabular}{lccccc}
\hline Extract & $\begin{array}{c}\text { Year, month and } \\
\text { season of collection }\end{array}$ & $\begin{array}{c}\text { Temperature } \\
\left(\text { mean; }{ }^{\circ} \mathrm{C}\right)\end{array}$ & $\begin{array}{c}\text { Rainfall } \\
(\mathrm{mm})\end{array}$ & $\begin{array}{c}\text { No. of } \\
\text { assays }\end{array}$ & $\begin{array}{c}\mathrm{Q}_{1 / 2}(\mu \mathrm{g} / \mathrm{mL}) \pm \\
\text { confidence interval }\end{array}$ \\
\hline Lot 2 & 1998; April; autumn ${ }^{\mathrm{a}}$ & 33 & 143.8 & 5 & $3.9 \pm 0.3$ \\
Lot 3 & 1999; April; autumn ${ }^{\mathrm{a}}$ & 32 & 12.8 & 3 & $3.6 \pm 0.1$ \\
\hline
\end{tabular}

a in the Southern Hemisphere. 
treated with smaller doses of the extract for a shorter period. We observed a clear effect on learning performance in aged rats treated for 45 days with 25 and $50 \mathrm{mg} / \mathrm{kg}$ of lot 3 ; the number of sessions to achieve the learning criteria was similar to that for young animals, and smaller than the number of sessions for aged controls (Figure 2). This study shows that BST0298 extract reverted the memory impairment observed in aged rats with a shorter treatment period and smaller doses than the previous study.

Several studies suggest that the cholinergic system is involved in the learning and memory process (Miranda et al., 2003; Hasselmo, 2006). Drugs which inhibit the metabolism of acetylcholine, such as physostigmine (Mukherjee et al., 2007), and direct cholinergic agonists, such as arecoline, oxotremorine, and bethanechol (Merlini, Pinza, 1989) have shown beneficial effects on memory in experimental studies. Anticholinesterase drugs, such as tacrine, donepezil, rivastigmine, and galantamine, are available for the treatment of Alzheimer disease (Perneczky, Kurz, 2004; Mukherjee et al., 2007). Muscarinic antagonists, such as scopolamine, are experimentally used as markers for the study of drugs that possibly modulate this neuronal system, since they cause performance impairment in animals in several different memory tasks (Quirarte et al., 1994; Heo et al., 2006). Aiming to verify whether the extract of $H$. aphrodisiaca acts by a cholinergic mechanism, we have evaluated its ability to prevent the amnesic effect of scopolamine in mice. In the passive avoidance test of the present study, no performance improvement was observed for animals with scopolamine-induced amnesia treated with the BST0298 extract (acutely or for 7 or 21 days). Results for extract-treated animals were similar to those receiving only scopolamine, showing that the chemical components of the extract probably are not muscarinic agonists. In addition, these animals did not display typical cholinergic side effects, such as tremors or chromodacryorrhea, which can be observed with cholinergic drugs (Espínola, Oliveira, Carlini, 1999).

It is unclear whether the effects of the H. aphrodisiaca extract could be attributed to one or more of its chemical constituents, since preliminary assays revealed the presence of several compounds in the extract, such as flavonoid glycosides, cardiac glycosides with steroidal nuclei, aromatic glycosides with a five-membered lactone ring, saponins, hydrolysable and condensed tannins, and nitro compounds (Galvão, 1997; Galvão et al., 2002). The phytochemical characterization of the BST0298 extract employed in the present study showed the presence of flavonoids astilbin, neoastilbin, and isoastilbin, well characterized (see Figure 1 and text in Material and Methods) and identified by HPLC, and an aliphatic nitro compound known as 2,3,4,6-tetra- $O$-(3-nitropropanoyl)- $O$ - $\beta$-Dglucopyranoside (Roman Júnior et al., 2005; Marques et al., 2007). However, no positive effect of these flavonoids on memory has been reported in the literature.

It is known that many plants protect against the effects of oxidative stress and that their antioxidant capacity is attributable to the presence of compounds such as flavonoids, tannins, and saponins (Packer, Hiramatsu, Yoshikawa, 1999; Ng, Liu, Wang, 2000). Antioxidant and radical scavenger properties have been described for the flavonoid astilbin (de la Morena, Pérez, 1999; Petacci et al., 2010). The increase in free radical generation has been implicated as one of the important mechanisms of cognitive impairment. Moderate/controlled levels of oxidative modifications are necessary to provide the hormetic central underpinning of neuroprotective response (Calabrese et al., 2010; Mattei, et al., 2011). Thus, the results of the in vitro lipid peroxidation of rat homogenates suggest that extract BST0298 has components that inhibit the interaction of free radicals with biomolecules present in the brain (Mattei et al., 2001). It is known that antioxidants have an important neuroprotective role in several neurodegenerative disorders such as Parkinson disease, Alzheimer disease, and other cognitive dysfunctions (Ng, Liu, Wang, 2000; Moosmann, Behl, 2002). In fact, the BST0298 extract possesses a rather marked antioxidant property, which can contribute to its beneficial effect on memory (Mattei et al., 2001). However, since the extract was effective in aged animals which already had learning and memory deficits, it seems unlikely that a preventive antioxidant would be completely responsible for the effects of the extract.

\section{CONCLUSION}

This work shows that the hydroalcoholic extract of $H$. aphrodisiaca was effective in improving the memory of aged animals in a T-maze after repeated administration of small doses, but had no effect on the scopolamine-induced amnesia test. These results suggest that repeated treatment with $H$. aphrodisiaca improves learning and memory by a non-muscarinic mechanism. The extract presented marked antioxidant activity, which can contribute to its beneficial effect on memory.

\section{ACKNOWLEDGEMENTS}

The authors would like to thank Dr. Miramy Macedo (Federal University of Mato Grosso) for the identification of the plant material. This research was financed by Laboratório Biosintética Ltda, and by Associação Fundo de Incentivo à Psicofarmacologia (AFIP). 


\section{REFERENCES}

CALABRESE, V.; CORNELIUS, C.; DINKOVA-KOSTOVA, A.T.; CALABRESE, E.J.; MATTSON, M.P. Cellular stress responses, the hormesis paradigm, and vitagenes: novel targets for therapeutic intervention in neurodegenerative disorders. Antioxid. Redox Signal., v.13, n.11, p.1763-1811, 2010 .

DE LA MORENA, G.S.; PÉREZ, J.M. Efecto hepatoprotector inducido por el flavonoide astilbina frente a un modelo animal tratado con tetracloruro de carbono. Rev. Cubana Plant. Med., v.1, n.1, p.36-39, 1999.

ESPÍNOLA, E.B.; OLIVEIRA, M.G.M.; CARLINI, E.A. Differences in central and peripheral responses to oxotremorine in young and aged rats. Pharmacol. Biochem. Behav., v.62, n.3, p.419-423, 1999.

GALVÃO, S.M.P.; MARQUES, L.C.; OLIVEIRA, M.G.M.; CARLINI, E.A. Heteropterys aphrodisiaca (extract BST0298): a Brazilian plant that improves memory deficits in old rats. J. Ethnopharmacol., v.79, n.3, p.305-311, 2002.

GALVÃO, S.M.P. Estudos farmacológicos e toxicológicos de Heteropteris aphrodisiaca O. Mach. - Malpighiaceae (nóde-cachorro) em roedores jovens e idosos. São Paulo, 1997. 163 p. [Dissertation of Máster degree. Federal University of São Paulo].

HASSELMO, M.E. The role of acetylcholine in learning and memory. Curr. Opin. Neurobiol., v.16, n.6, p.710-715, 2006.

HEO, H.J.; SUH, Y.M.; KIM, M.J.; CHOI, S.J.; MUN, N.S.; KIM, H.K.; KIM, E.; KIM, C.J.; CHO, H.Y.; KIM, Y.J.; SHIN, D.H. Daidzein activates choline acetyltransferase from MC-IXC cells and improves drug-induced amnesia. Biosci. Biotechnol. Biochem., v.70, n.1, p.107-111, 2006.

HSIEH, M.T.; PENG, W.H.; WU, C.R.; WANG, W.H. The ameliorating effects of the cognitive-enhancing Chinese herbs on scopolamine-induced amnesia in rats. Phytother. Res., v.14, n.5, p.375-377, 2000.

KARTNIG, T.; WEGSCHAIDER, O. Possible identification of sugars from small amounts of glycosides or sugar mixtures. J. Chromatogr. A, v.61, n.2, p.375-376, 1971.
LEE, S.C.; MOON, Y.S.; YOU, K.H. Effects of red gingeng saponins and nootropic drugs on impaired acquisition of ethanol-treated rats in passive avoidance performance. $J$. Ethnopharmacol., v.69, n.1, p.1-8, 2000.

MARQUES, L.C.; PIERRE, C.; ROMAN-JÚNIOR, W.A.; CARDOSO, M.L.C.; MILANEZE-GUTIERRE, M.A.; MELLO, J.C.P. Controle farmacognóstico das raízes de Heteropterys aphrodisiaca O. Mach. (Malpiguiaceae). Rev. Bras. Farmacog., v.17, n.4, p.604-615, 2007.

MATTEI, R.; BARROS, M.P.; GALVÃO, S.M.P.; BECHARA, E.J.H.; CARLINI, E.A. Heteropterys aphrodisiaca O. Machado: effects of extract BST0298 on the oxidative stress of young and old rat brains. Phytother. Res., v.15, n.7, p.604-607, 2001.

MATTEI, R.; POLOTOW, G.T.; VARDARIS, C.V.; GUERRA, B.A.; LEITE, J.R.; OTTON, R.; BARROS, P.M. Astaxanthin limits fish oil-related oxidative insult in the anterior forebrain of Wistar rats: putative anxiolytic effects? Pharmacol. Biochem. Behav, v.99, n.3, p.349-355, 2011.

MENDES, F.R.; CARLINI, E.A. Brazilian plants as possible adaptogens: an ethnopharmacological survey of books edited in Brazil. J. Ethnopharmacol., v.109, n.3, p.493500, 2007.

MERLINI, L.; PINZA, M. Trends in searching for new cognition enhancing drugs. Prog. Neuropsychopharmacol. Biol. Psychiatry., v.13, suppl., p.S61-S75, 1989.

MIRANDA, M.I.; FERREIRA, G.; RAMIREZ-LUGO, L.; BERMÚDEZ-RATTONI, F. Role of cholinergic system on the construction of memories: taste memory encoding. Neurobiol. Learn. Mem., v.80, n.3, p.211-222, 2003.

MOOSMANN, B.; BEHL. C. Antioxidants as treatment for neurodegenerative disorders. Expert. Opin. Investig. Drugs, v.11, n.10, p.1407-1435, 2002.

MUKHERJEE, P.K.; KUMAR, V.; MAL, M.; HOUGHTON, P.J. Acetylcholinesterase inhibitors from plants. Phytomedicine, v.14, n.4, p.289-300, 2007.

NG, T.B.; LIU, F.; WANG, Z.T. Antioxidative activity of natural products from plants. Life Sci., v.66, n.8, p.709-723, 2000. 
NITTA, H.; MATSUMOTO, K.; SHIMIZU, M.; NI, X.H.; WATANABE, H. Panax ginseng extract improves the performance of aged fischer 344 rats in radial maze task but not in operant brightness discrimination task. Biol. Pharm. Bull., v.18, n.9, p.1286-1288, 1995.

PACKER, L.; HIRAMATSU, M.; YOSHIKAWA, T. Antioxidant food supplements in human health. San Diego: Academic Press, 1999. $511 \mathrm{p}$.

PERNECZKY, R.; KURZ, A. Current antidementive therapy. MMW Fortschr. Med., v.146, n.2 (spec.), p.53-56, 2004.

PETACCI, F.; FREITAS, S.S.; BRUNETTI, I.L.; KHALIL, N.M. Inhinbition of peroxidase activity and scavenging of reactive oxygen species by astilbin isolated from Dimorphandra mollis (Fabaceae, Caesalpinioideae). Biol. Res., v.43, n.1, p.63-74, 2010.

PETKOV, V.D.; BELCHEVA, S.; PETKOV, V.V. Behavioral effects of Ginkgo biloba L., Panax ginseng C.A. Mey. and Gincosan. Am. J. Chin. Med., v.31, n.6, p.841-855, 2003.

POTT, A.; POTT, V.J. Plantas do Pantanal. Corumbá: EMBRAPA - SPI, 1994. p.101.

QUIRARTE, G.L.; CRUZ-MORALES, S.E.; CEPEDA, A.; GARCIA-MONTAÑEZ, M.; ROLDÁN-ROLDÁN, G.; PRADO-ALCALÁ, R.A. Effects of central muscarinic blockade on passive avoidance: anterograde amnesia, state dependency, or both? Behav. Neural Biol., v.62, n.1, p.1520, 1994.
ROMAN JÚNIOR, W.A.; CARDOSO, M.L.C.; VILEGAS, W.; NAKAMURA, C.V.; DIAS FILHO, B.P.; MELLO, J.C.P. 2,3,4,6-tetra-O-(3-nitropropanoyl)-O- $\beta$-Dglucopyranoside, a new antimicrobial from the roots of Heteropteris aphrodisiaca. Acta Farm. Bonaerense, v.24, n.4, p.543-545, 2005.

ROMAN JÚNIOR, W.A. Identificação de nitrocomposto e dihidroflavonóis, atividades antibacteriana, antifúngica e antiviral de substâncias isoladas dos extratos liofilizados das raizes de Heteropteris aphrodisiaca $O$. Mach., Malpighiaceae, nó-de-cachorro. Araraquara, 2003. 132 p. [Dissertation of Máster degree. State University of São Paulo "Júlio de Mesquita Filho"].

STOCKS, J.; GUTTERIDGE, J.M.C.; SHARP, J.; DORMANDY, T.L. Assay using brain homogenates for measuring the antioxidant activity of biological fluids. Clin. Sci. Mol. Med., v.47, n.3, p.215-222, 1974.

VOIGT, R. Pharmazeutische technologie. 7.ed. Berlin: Ullstein Mosby, 1993. p.496-504.

Received for publication on $12^{\text {th }}$ May 2011 Accepted for publication on $05^{\text {th }}$ July 2011 